\title{
Lead and Zinc in Soils Around a Zinc-Works - Presence, Mobility and Environmental Risk
}

\author{
Alicja Kicińska' \\ 1 AGH University of Science and Technology,Department of Environmental Protection, Faculty of Geology, \\ Geophysics and Environmental Protection,al. Mickiewicza 30, 30-059 Kraków, Poland \\ e-mail: kicinska@geol.agh.edu.pl
}

\begin{abstract}
The aim of this paper was to analyse the impact of long-term operation of a zinc-works on the soil environment based on 20-year observations. The study material comprised the surface soil samples and soil profiles collected in close vicinity of the zinc-works in Miasteczko Śląskie (Southern Poland) and in the locations within certain distance from the plant. The total content of $\mathrm{Pb}$ and $\mathrm{Zn}$ in the surface soil samples collected in the vicinity of the zinc-works in 2018 ranged from 3,975 to 26,200 mg/kg for Pb and from 3,358 to 21,867 mg/kg for Zn. These values were considerably higher than those recorded 20 years earlier (i.e. $601-11,939 \mathrm{mg} / \mathrm{kg}$ and 1,009-13,924 mg/kg for $\mathrm{Pb}$ and $\mathrm{Zn}$, respectively). The mineral composition was dominated by quartz, feldspars and carbonates (e.g. calcium carbonate). Additionally, iron hydroxides (lepidocrocite), lead sulphates (anglesite) and zinc silicates (hemimorphite) were found. The bioavailable quantities of $\mathrm{Pb}$ and $\mathrm{Zn}$ in the soil samples collected in 2018 amounted to $30 \%$ of the total content in the case of $\mathrm{Pb}$ and $34 \%$ of the total $\mathrm{Zn}$ content. Twenty years earlier, the mean values were $66 \%(\mathrm{~Pb})$ and $44 \%(\mathrm{Zn})$, respectively. The acidity of the soil samples collected in the vicinity of the zincworks indicated their very good buffering capacity, as well as the capacity to release $58-60 \%$ of the total $\mathrm{Pb}$ and $\mathrm{Zn}$ contents to the environment, with a $\mathrm{pH}$ decrease of only 3 units. The Risk Assessment Code (RAC) calculated based on the $\mathrm{Pb}$ and $\mathrm{Zn}$ cations in the exchangeable positions and bound with carbonates indicates that even after 20 years, there is still a high environmental risk related to the presence of those metals in soils. This paper also demonstrates that presently the major factors contributing to the pollution of soil are deflation and suffosion of small particles from the old, unprotected mining and industrial waste dumps.
\end{abstract}

Keywords: zinc and lead metallurgy, soils, contamination factor, geo-accumulation index, RAC.

\section{INTRODUCTION}

The impact of a zinc-works on the soil environment in its vicinity is visible in multiple aspects. These include the immission of the industrial fly-ash onto the top level of the soil profile, but also the introduction of various forms of metals (metal fractions) which are not naturally found in soils. The subsequent changes related to e.g. weathering, deflation or suffosion of the smallest soil particles, aided by natural and anthropogenic factors affect the behavior of elements originally integrated into the crystal structures of metal ores (Jena et al. 2019, Kicińska and Bożęcki 2018, Kicińska 2018). These changes cause an increase in the total content of elements in soils (this pertains to both primary elements i.e. $\mathrm{Zn}$ and $\mathrm{Pb}$, and secondary elements e.g. $\mathrm{Fe}, \mathrm{Cu}, \mathrm{As}, \mathrm{Cd}, \mathrm{Sn}$, $\mathrm{Tl}, \mathrm{Ag}, \mathrm{Ge}$ and $\mathrm{Bi}$ ) and an increase in the mobility and chemical activity of metals, which results in the creation of single bonds with other ions or organic substances present in soils. The decrease of the bond strength between ions facilitates their penetration into other geospheres as well as their consumption by living organisms, which is observed through the biomagnification process occurring in the highly polluted areas (Dziubanek et al. 2017, Kicińska 2019b, Hadzi et al. 2019, Kapusta et al. 2019, Kicińska and Jelonek-Waliszewska 2017, Qui 2010).

Despite employing modern pollution control methods, the contemporary metal-works are 
still unable to completely eliminate their negative impact on the soil and plant structure in their closest vicinity (Bączek-Kwinta et al. 2019). The historical pollution and its characteristics are also important. The metallurgical pollutants have the ability to disperse widely and their composition depends not only on the processed ore (or concentrate) type, but also on the climate conditions, which may generate secondary pollution. In addition to the above, such pollutants have a severe impact on the living organisms, expressed by the inheritance of resistance to metals, and delayed effects resulting from the metal accumulation in soils (Kicińska 2016).

There are over one thousand known $\mathrm{Zn}$ ore deposits around the world. Their geological resources are estimated at 900 million tons of $\mathrm{Zn}$, over $8 \%$ of which are found in Poland. Th zinc mining in the EU is decreasing because the reserves are depleting. On the other hand, in North America, Australia and several South American countries (e.g. Chile, Mexico and Peru), the mining of this metal is increasing. The most important ores used in the production of $\mathrm{Zn}-\mathrm{Pb}$ are sulphide ores, amounting to $90 \%$ of the global production (Kicki 1997). They are characterised by a large content of accompanying elements, which may result in the need to process and store industrial waste, creating an additional burden for the environment (Kicińska 2019a, Kosa and Kicińska 2016, Nowińska 2003).

Over the last two decades, considerable advancements have been made in the field of reducing the industrial pollutant emissions containing gases, dust, heavy metals, etc. (CSO 2019, Data on Poland). In Poland, in the years 2000-2017, the dust emissions from plants that are particularly harmful to air quality were reduced by $80 \%$, while the gas emissions were reduced by $34 \%$. Undoubtedly, this was possible due to the quantity and quality of projects implemented as part of the EU and national environmental policies. Comparing the statistical data on the industrial emissions of heavy metals (i.e. $\mathrm{Cr}, \mathrm{Zn}, \mathrm{Cd}, \mathrm{Cu}$, $\mathrm{Ni}$, and $\mathrm{Hg}$ ) from various times in the previous two decades, it is possible to confirm a considerable decrease in the quantities of all the abovementioned elements. Only in the case of $\mathrm{Pb}$, the emissions increased by about $2 \%$. However, even though positive changes are observed, the emission of pollutants continues, especially in the heavily industrialised areas. In Poland, as many as 615 tons of $\mathrm{Zn}$ and 309 tons of $\mathrm{Pb}$ were emitted as a result of industrial combustion and production processes in 2016 (Data on Poland).

In light of the above, research has been conducted over the last 20 years in the vicinity of one of the largest zinc-works in Poland (in Miasteczko Śląskie) to establish: (i) the changes in the total content of $\mathrm{Zn}$ and $\mathrm{Pb}$ in soils, (ii) the mineral forms in which these metals are found, (iii) the quantity of their bioavailable forms, (iv) the changes in the mobility of $\mathrm{Zn}$ and $\mathrm{Pb}$ in the soil environment caused by its acidification. An additional purpose of the research was $(v)$ to calculate and analyse the Risk Assessment Code (RAC) of the soil samples collected from the close vicinity of the zinc-works in 2018 and 1998 with regard to the $\mathrm{Zn}$ and $\mathrm{Pb}$ content.

\section{STUDY AREA}

The "Miasteczko Śląskie" zinc-works was built in the years 1960-1972 and is located in the north part of the town bearing the same name. It is located in the Śląskie Province (in Southern Poland), about $30 \mathrm{~km}$ from Katowice, the capital of the most industrialised region in Poland. The plant is the only one in Poland and one of eight in the world producing $\mathrm{Zn}$ and $\mathrm{Pb}$ using the Imperial Smelting Process (ISP). The feed mixture used in the process includes primary raw materials ( $\mathrm{Zn}-\mathrm{Pb}$ concentrates and raw $\mathrm{Zn}$ oxide) and secondary, recycled materials containing $\mathrm{Zn}-\mathrm{Pb}$ e.g. dust, sludge, melting loss and steel mill dust (Nowińska 2003).

Currently, the zinc-works produces 80 thousand tons of $\mathrm{Zn}$ and 600 tons of $\mathrm{Pb}$, which amounts to $44 \%$ and $53 \%$ of the total Polish production, respectively. The metallurgical plant comprises the following departments: sintering plant with a $\mathrm{H}_{2} \mathrm{SO}_{4}$ factory and Cd plant, shaft furnace, as well as $\mathrm{Pb}$ refining and $\mathrm{Zn}$ rectification plants.

In the 1990s, the plant was ranked as one of the 90 largest polluters in Europe. From the north the facility borders with a forest, to the south $-\mathrm{a}$ buffer zone with limited use, while to the west - a railway line. Over the last two decades, the zinc-works has implemented high-cost environmental protection projects. As a result, the plant has become an industry-wide innovator and has continuously strived to protect the environment.

The major soil types in the vicinity of Miasteczko Śląskie include podsols, pseudo-podsols and weakly loamy soils. Poorly formed rendzina 
soils and brown earth soils are found as well. The prevailing winds in the region are western and north-western (35.5\% of the year) and the annual precipitation is $640 \mathrm{~mm}$.

\section{MATERIALS AND METHODS}

In the years 1998 and 2018, ten (10) independent soil samples were collected at each of 4 sites differing in distance and location in relation to the zinc-works in Miasteczko Śląskie. Each sample was collected from the depth of $0-20 \mathrm{~cm}$ below ground level. In site no. 1, the samples were collected at $5 \mathrm{~cm}$ intervals, starting from the ground level to a depth of $50 \mathrm{~cm}$ below ground level (Fig. 1). The weight of each sample was about $0.5 \mathrm{~kg}$. The soil samples were dried at a room temperature, sieved using a sieve with $2 \mathrm{~mm}$ mesh, averaged, reduced and dehumidified.

The $\mathrm{Pb}$ and $\mathrm{Zn}$ content was determined in each of the samples:

- leached by water solution (1:10 ratio between the solid phase and solution),

- phytoavailable, determined by single extraction using 0.11 M EDTA solution (1:10 ratio between the solid phase and solution) (Manouchehri et al. 2006),

- pseudo-total, determined by extraction in aqua regia $(\mathrm{HCl}+\mathrm{HNO} 3$, at the ratio of $3: 1)$ in an SCP SCIENCE microwave oven, type DigiPREP HT, at $130^{\circ} \mathrm{C}$,

- extracted from the soil using solutions with increasing acidity, by addition of 7 doses of acid from 0 to $120 \mathrm{mmol} \mathrm{HNO}^{3} / \mathrm{dm}^{3}$.
In the case of the surface samples, 10 individual samples were taken for each sampling campaign (1998 and 2018) and for each sampling site $(1-4)$. Then, the averaged samples $(n=8)$ were prepared, consisting of the mixture of the 10 samples collected at each site. BCR sequential extraction was performed on these averaged samples, according to the procedure described in detail in a paper by Kicińska (2019a).

Determination of the phase composition and chemical composition was performed using XRD (X-Ray Diffraction, Rigaku MiniFlex 600 XRD diffractometer) and XRF (X-Ray Fluorescence method, Rigaku WD-XRF ZSX Primus II spectrometer, X-ray tube). This methodology was described in detail in (Kicińska 2019a).

The chemical composition was determined using the induced coupled plasma mass emission spectroscopy method (ICP-MS) at a certified geochemical laboratory (certificate no. AB1050) of the AGH University of Science and Technology. CRM048, Lot LRAB1604 was used as a reference material. The precision of the $\mathrm{Pb}$ and $\mathrm{Zn}$ content determination was $8 \%$, while the accuracies (AO) ranged between 95.2 and $98.2 \%$. The limits of detection (LOD) and quantification (LOQ) were calculated in accordance with the formulas presented in (Kicińska 2019a). The values are shown in Table 1. Air-dried and sieved ( $2 \mathrm{~mm}$ ) soil was used for the determination of the $\mathrm{pH}$ and OM content using standard protocols (Sparks 1996).

The following indices were used to evaluate the degree of soil contamination with $\mathrm{Pb}$ and $\mathrm{Zn}$ : Contamination Factor $(C F)$, Geoaccumulation In$\operatorname{dex}\left(I_{g e o}\right)$ and Pollution Load Index $(P L I)$.

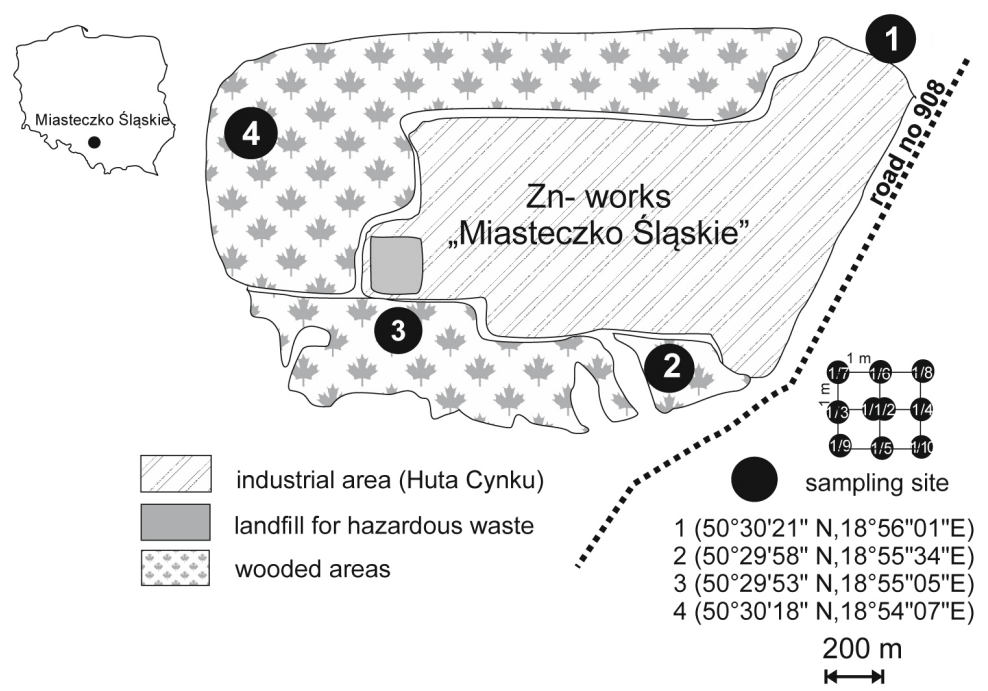

Figure 1. Sampling sites location in 1998 and 2018 
Table 1. The mean content of $\mathrm{Pb}$ and $\mathrm{Zn}$ in the surface soils samples from the surrounding of the $\mathrm{Zn}$-works

\begin{tabular}{|c|c|c|c|c|c|}
\hline \multirow{2}{*}{\multicolumn{2}{|c|}{ Parameters }} & \multicolumn{2}{|c|}{$\mathrm{Pb}$} & \multicolumn{2}{|c|}{$\mathrm{Zn}$} \\
\hline & & \multicolumn{4}{|c|}{$\left(\mathrm{mg} \cdot \mathrm{kg}^{-1}\right)$} \\
\hline CRM & \begin{tabular}{|l|} 
reference values \\
measure values \\
$(\mathrm{AO} \%)$
\end{tabular} & \multicolumn{2}{|c|}{$\begin{array}{l}145 \pm 3.81 \\
138 \pm 4.55 \\
\quad(95.2)\end{array}$} & \multicolumn{2}{|c|}{$\begin{array}{c}770 \pm 17.1 \\
756 \pm 21.0 \\
(98.2)\end{array}$} \\
\hline & $\begin{array}{l}\text { LOD } \\
\text { LOQ }\end{array}$ & \multicolumn{2}{|c|}{$\begin{array}{l}0.0014 \\
0.0034\end{array}$} & \multicolumn{2}{|c|}{$\begin{array}{l}0.0013 \\
0.0029\end{array}$} \\
\hline \multirow{2}{*}{\multicolumn{2}{|c|}{ Sample sites }} & \multicolumn{4}{|c|}{ year } \\
\hline & & $1998^{b}$ & $2018^{a}$ & 1998 & 2018 \\
\hline & $1(n=10)$ & $2217 \pm 136$ & $26,200 \pm 59$ & $2898 \pm 44$ & $20,877 \pm 59$ \\
\hline & $2(n=10)$ & $11,939 \pm 112$ & $7736 \pm 18$ & $13,924 \pm 364$ & $4525 \pm 14$ \\
\hline & $3(n=10)$ & $601 \pm 12$ & $3975 \pm 56$ & $1009 \pm 71$ & $3358 \pm 29$ \\
\hline & $4(n=10)$ & $3764 \pm 24$ & $18,651 \pm 126$ & $2870 \pm 44$ & $21,867 \pm 79$ \\
\hline \multicolumn{6}{|c|}{ For all samples $(n=40)$} \\
\hline & $A v \pm S D$ & $4630 \pm 4365$ & $14,141 \pm 8805$ & $5175 \pm 5109$ & $12,657 \pm 8732$ \\
\hline & $\mathrm{Me}$ & 2991 & 13,194 & 2884 & 12,701 \\
\hline & $\mathrm{V}$ & 0.94 & 0.62 & 0.99 & 0.69 \\
\hline $\begin{array}{l}\text { Upper lir } \\
\text { II catego } \\
\text { IV categ }\end{array}$ & $\begin{array}{l}\text { t determined for soil belonging to: } \\
(\% \text { of samples exceed this limit) } \\
{ }^{c} \text { (\% of samples exceed this limit) }\end{array}$ & \multicolumn{2}{|c|}{$\begin{array}{c}100-500(100 \%) \\
600(100 \%)\end{array}$} & \multicolumn{2}{|c|}{$\begin{array}{c}300-1000(100 \%) \\
2000(100 \%)\end{array}$} \\
\hline $\begin{array}{l}\text { Natural } \\
\text { limit }^{\mathrm{d}}\end{array}$ & ntent ${ }^{\mathrm{d}}(\%$ of samples exceed this & \multicolumn{2}{|c|}{$2-90(100 \%)$} & \multicolumn{2}{|c|}{$30-100(100 \%)$} \\
\hline
\end{tabular}

CRM - certified research material (Lot LRAB1604, ID CRM048), LOD - limit of detection, LOQ - limit of quantification, AO - analysis trueness, SD - standard deviation, Av - arithmetic average, Me - median,

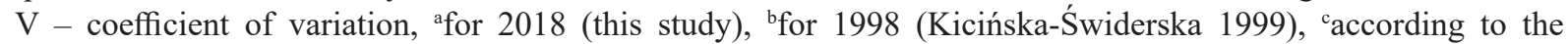
Regulation of the Minister of the Environment (2016) for 2018 sampling only: II category - arable land, orchards, pastures, permanent meadows, IV category - industrial areas, mining areas, communication areas, ${ }^{\mathrm{d}}$ according to Kabata-Pendias and Szteke (2012) for the appropriate type of soil.

The Contamination Factor $(C F)$ was calculated as the ratio between the element content in soil and its geochemical background. Using this factor for pollution evaluation, Håkanson (Håkanson 1980) distinguished 4 classes: L - low $(C F<1), \mathrm{M}-$ moderate $(1 \leq C F<3), \mathrm{C}$ - considerable $(3 \leq C F<6)$ and $\mathrm{VH}$ - very high $(C F \geq 6)$ degree of contamination.

The Geoaccumulation Index $\left(I_{\text {geo }}\right)$ also represents the ratio between the determined $\mathrm{Pb}$ or $\mathrm{Zn}$ content in soil and its geochemical background, but it is also multiplied by 1.5 . The factor 1.5 is introduced to include the possible variation of the background values due to the lithogenic effect (Müller 1981). The $I_{g e o}$ index allows for classifying soils according to one of 7 classes, from 0 - representing no pollution to VI - representing extreme pollution.

Finally, the Pollution Load Index (PLI) represents the total pollution calculated for $\mathrm{Zn}$ and $\mathrm{Pb}$. This index was calculated using the formula below:

$$
P L I=\sqrt[n]{\operatorname{ConcFPb} \cdot \operatorname{ConcFZn}}
$$

where: $\operatorname{Con} c F P b$ - denotes the relation between the $\mathrm{Pb}$ content in the sample and its geochemical background (Kabata-Pendias and Pendias 1999, Regulation 2016), $\mathrm{n}$ equals the number of contamination factors.If $P L I<1$, there is no pollution, if $P L I>1$, the environmental matrix is polluted.

The Environmental Risk Code (RAC) was calculated in two ways: 1) as the ratio between the quantity extracted using the $0.11 \mathrm{M}$ EDTA solution (phytoavailable fraction) and the total content and 2) as the ratio between the content extracted in Step I of BCR (exchangeable and carbonate fraction) and the total content. Due to its complexing abilities, the $0.11 \mathrm{M}$ EDTA solution extracts more metal ions than the 0.1 $\mathrm{M} \mathrm{CH} \mathrm{COOH}_{3}$ solution which causes disruption of decidedly weaker bonds, and release of the ions located in the exchangeable positions and bound with carbonates. The ratio between 1 and $10 \%$ denotes low risk, $11-30 \%$ medium risk, $31-50 \%$ high risk and the values above 
$50 \%$ indicate a very high risk to the environment (Kicińska 2019b).

The statistical calculations were conducted with the Statistica ver. 13.1 and Excel applications. The differences between means were detected by the Tukey's HSD test at a significance level of 0.05 .

\section{RESULTS}

\section{Chemical and phase composition of soil samples}

The substances commonly found in soils were identified in the samples i.e. Si, Al., Fe, Ca, $\mathrm{K}, \mathrm{Mg}$ and $\mathrm{P}$ oxides. Their content did not differ considerably from the chemical composition of the unpolluted soils found in Poland (KabataPendias and Pendias 1999): the dominant component was silica, comprising $69-80 \%$ mass, while $\mathrm{Al}_{2} \mathrm{O}_{3}(5-8 \%), \mathrm{Fe}(3-6 \%), \mathrm{CaO}(2-9 \%), \mathrm{K}$ (1-2\%), $\mathrm{Mg}(0.6-1.3 \%)$ and $\mathrm{P}(0.1-0.3 \%)$ were found in smaller quantities. Additionally, $\mathrm{S}(<1 \%$ mass) as well as $\mathrm{Ti}, \mathrm{Na}, \mathrm{Cu}$ and $\mathrm{Mn}(<0.5 \%$ mass $)$ were found. The analysis confirmed the presence of trace quantities ( $<0.1 \%$ mass) of $\mathrm{As}, \mathrm{Ba}, \mathrm{Bi}, \mathrm{Cl}$, $\mathrm{Cr}, \mathrm{Ni}, \mathrm{Rb}, \mathrm{Se}, \mathrm{Sn}, \mathrm{Sr}, \mathrm{Tl}, \mathrm{Y}$ and Zr.

The XRF method allowed for detecting a high content of $\mathrm{Zn}(6051-47,374 \mathrm{mg} / \mathrm{kg}), \mathrm{Pb}$ (4950$40,812 \mathrm{mg} / \mathrm{kg}$ ) and $\mathrm{Cd}(262-6302 \mathrm{mg} / \mathrm{kg})$, while the natural content of these elements in soils ranges from: $35-80,13-25$ and $0.05-0.5(\mathrm{mg} / \mathrm{kg})$, respectively (as stated in Regulation 2016).

The most abundant minerals in the composition of the soils studied were mostly silicates (quartz), aluminosilicates (albite and sanidine), carbonates (dolomite and calcite) and finely grained minerals (illite and kaolinite). Due to the sensitivity of the XRD method $(<0.5 \%)$, zinc sulphide - sphalerite $(\mathrm{ZnS})$ was found in only one of the samples (site no. 3, Fig. 1). While the former are typical minerals found in the soils formed on carbonate substrate, the presence of zinc blende indicates an excessive content of $\mathrm{Zn}$ in the soil.

The contents of $\mathrm{Pb}$ and $\mathrm{Zn}$ determined by extraction using a mixture of concentrated acids in the surface soil samples collected in 2018 vary between $3,975-26,200 \mathrm{mg} / \mathrm{kg}$ and $3,358-21,867 \mathrm{mg} / \mathrm{kg}$, respectively (Tab. 1). Having compared these values with those listed in the Regulation of the Minister of the Environment (Regulation 2014) on the assessment of ground pollution as limits for $\mathrm{Pb}$ and $\mathrm{Zn}$ for the category II soils (arable land, orchards and pastures) amounting to 100 and $300 \mathrm{mg} / \mathrm{kg}$ respectively, and for the category IV soils (industrial areas, mining areas and communication areas) amounting to 600 and $2000 \mathrm{mg} / \mathrm{kg}$ respectively, it was concluded that the limits were exceeded in all the samples tested.

In the soil samples collected in 1998, the contents of the elements analysed varied from 601 to $11,939 \mathrm{mg} / \mathrm{kg}$ in the case of $\mathrm{Pb}$ and from 1,009 to $13,924 \mathrm{mg} / \mathrm{kg}$ in the case of $\mathrm{Zn}$. When comparing these values to the ones found in the same sites 20 years later, a considerable increase in the content of these two elements in the soil is visible. The analysis of the soil environment in close vicinity of the zinc-works in 2018 based on the median contents of both metals demonstrated that the content of $\mathrm{Pb}$ and $\mathrm{Zn}$ are four times higher than in 1998. In both sampling cycles, the concentrations of the elements studied are multiple times higher than their natural content.

The quantities of both elements determined in soils in the years 2018 and 1998 were analysed with regard to their spatial distribution (Fig. 2). In 1998, the highest concentrations of $\mathrm{Pb}$ and $\mathrm{Zn}$ were found in site no. 2 (Fig.1), while in 2018 the highest pollution levels were recorded in site no. $1(\mathrm{~Pb})$ and site no. $4(\mathrm{Zn})$. It was observed that the location of the sites most polluted with $\mathrm{Pb}$ and $\mathrm{Zn}$ changed over the two decades. In 1998, the most polluted soils were found in site no. 2 located about $50 \mathrm{~m}$ SE from the main furnaces, near the entry gate to the zinc-works. This was the site of the greatest immission of the industrial dust emitted by the smoke stacks of the zinc-works (accordingly to geographical directions). Moreover, the heavy road vehicle and railway traffic related to the supply of metal ores and transport of products from the plant had an impact on the condition of the soil environment. Twenty years later, the most polluted sites are site no. 1 and no. 4 located further away from the zinc-works (about $2 \mathrm{~km}$ away) and in another direction ( $\mathrm{N}$ and $\mathrm{NW}$ ). The present situation shows that there is no relation between pollution and the prevailing winds, and confirms the effectiveness of the actions taken by the zinc-works to reduce the pollutant emissions to the atmosphere. While analysing the spatial development of the areas around the zinc-works it was found that the present source of considerable emissions are without doubt the improperly restored former 

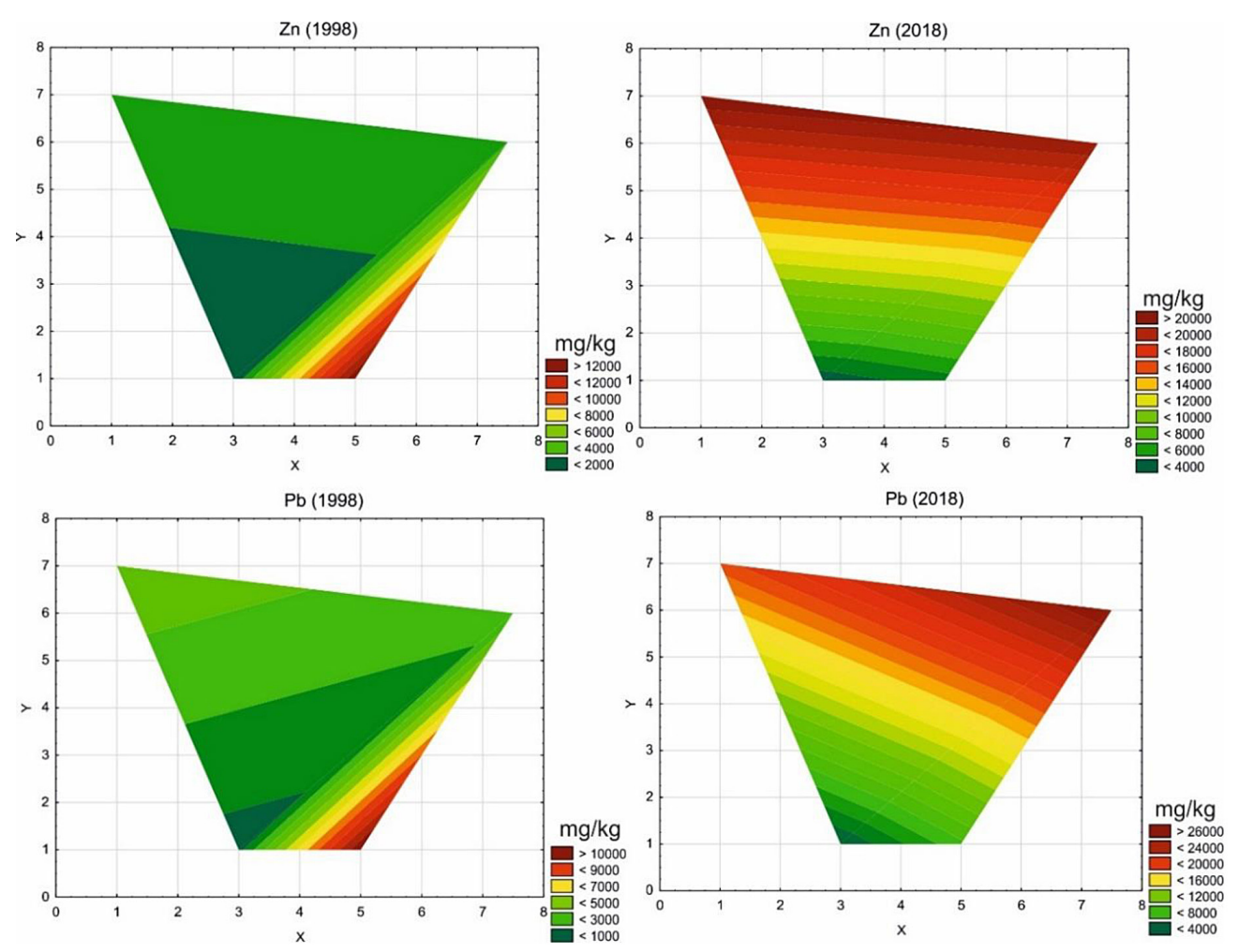

Figure 2. Spatial distribution of $\mathrm{Pb}$ and $\mathrm{Zn}$ in surface soils

industrial waste dumps. New loads of hazardous/toxic substances are continuously released from these weathering waste dumps.

Having analysed the vertical distribution of $\mathrm{Pb}$ and $\mathrm{Zn}$ in the soil profiles collected in 1998 and 2018, it was determined that their highest concentrations are found in surface soil layers i.e. at the depth of $0-15 \mathrm{~cm}$. The concentrations are 3-4 times greater than those measured in the layers located directly below them and 12-17 times greater than the values measured in the deepest layers i.e. $45-50 \mathrm{~cm}$ (Fig. 3). The contents of $\mathrm{Pb}$ and $\mathrm{Zn}$ measured in the soil profiles in 2018 are considerably higher than those recorded 20 years earlier. In the case of the surface soil layer, they are 12 times higher for $\mathrm{Pb}$ and 7 times higher for $\mathrm{Zn}$. In the deeper layers, the differences are less pronounced. Despite the considerable differences in the element concentrations in the surface layer and in the deeper layers, the concentrations recorded did not represent the values that may be considered comparable to the natural concentration at any of the levels. This confirms that for many years, if not for many centuries, the soil structure has been subject to pollution and to prolonged migration of toxic compounds into the soil profile, which has put ground water at the risk of contamination.

\section{Fractions binding $\mathrm{Pb}$ and $\mathrm{Zn}$ in soils}

The information on the various forms in which metals are found in soils is very important, especially in the context of the environmental risk evaluation. Therefore, using the BCR extraction, the authors determined the percentage share of the $\mathrm{Pb}$ and $\mathrm{Zn}$ cations in the ion exchange positions, bound with carbonates, reducible, bound with organic and oxidisable substances, and in the residual fraction (Fig. 4). In the year 2018, in the case of all soil samples, the share of the $\mathrm{Pb}$ and $\mathrm{Zn}$ cations in the ion exchange positions and bound with carbonates was $20 \%$ and $26 \%$, respectively. This share was $46 \%(\mathrm{~Pb})$ and $14 \%(\mathrm{Zn})$ lower than in 1998. This fraction includes labile metals bound with the solid fraction by physical and chemical adsorption and ion-exchange sorption. Metals are retained on the soil surface by relatively weak electrostatic forces and may be released in the course of ion exchange. This fraction also includes the $\mathrm{Pb}$ and $\mathrm{Zn}$ carbonates and forms that were adsorbed or coprecipitated with calcium carbonate, sulphides and phosphates. Thus, the share of cations in this fraction in unpolluted soils should amount to just a few per cent. The decreasing share of this fraction in soils is a very positive change. 


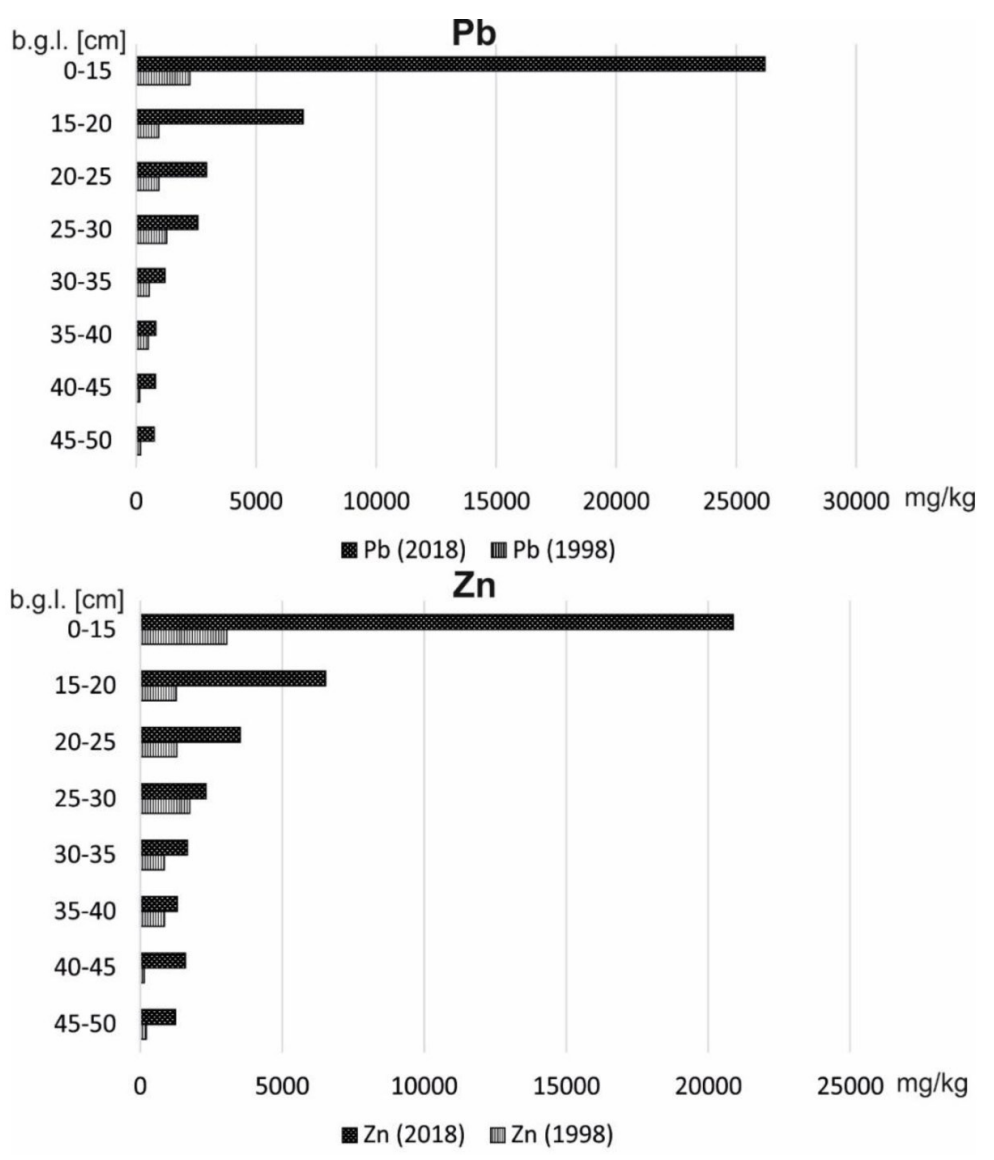

Figure 3. Vertical distribution of $\mathrm{Pb}$ and $\mathrm{Zn}$ in soil profile (site no. 1)

In the samples collected in 2018, the reducible fraction (Step II of BCR) amounted to $19 \%$ $(\mathrm{Pb})$ and $3 \%(\mathrm{Zn})$. In the case of $\mathrm{Pb}$, its share was $10 \%$ greater, while in the case of $\mathrm{Zn}-24 \%$ smaller as compared to the mean shares calculated for the soil samples collected two decades earlier.

In the 2018 samples, the organic and oxidisable fraction (Step III of BCR) amounted to 4\% $(\mathrm{Zn})$ and $1 \%(\mathrm{~Pb})$. These values were $20 \%$ and $23 \%$ lower than the results obtained 20 years earlier, respectively. The difference between the data recorded in 1998 and 2018 may be due to the quantitative and qualitative changes in the organic matter contained in soils. In 1998, TOC varied between $2.01 \%$ and $10.63 \%$, while two decades later it ranged between $4.5 \%$ and $12.38 \%$.

The share of the final fraction (Step IV of $\mathrm{BCR}$ - residual fraction) in the samples collected in 2018 was the greatest both in the case of $\mathrm{Pb}(60 \%)$ and $\mathrm{Zn}(67 \%)$. These values were $55 \%(\mathrm{~Pb})$ and $61 \%(\mathrm{Zn})$ higher than the results for the samples collected in 1998. This fraction comprises the metal cations permanently bound to the mineral components of the soil, both to primary minerals as well as to secondary minerals, built into their crystal structures. The recorded tendency is very beneficial for the environment.

In summary, the ratio between the readily mobile forms (Step I+II of BCR) and sparingly mobile forms (Step III+IV of BCR) in the soil samples collected in 2018 was 39:61 in the case of $\mathrm{Pb}$ and 29:71 in the case of $\mathrm{Zn}$. In the case of the samples collected 20 years earlier, this ratio was 75:25 (Pb) and 67:33 ( $\mathrm{Zn})$. These changes confirm the increasing share of more stable forms, which are less mobile and therefore not as readily released into the environment, especially into the water environment.

\section{Mobility of $\mathrm{Pb}$ and $\mathrm{Zn}$}

Water leaching of metals from soil is a measure of their quantity in the phase with the weakest bonds between molecules. It represents the quantity of cations that most readily leach into surface and ground water. The soil samples collected in 2018 were extracted to $0.10-1.59 \mathrm{mg} \mathrm{Pb} / \mathrm{dm}^{3}$ and $0.22-2.99 \mathrm{mg} \mathrm{Zn} / \mathrm{dm}^{3}$ water solutions. In the case of $\mathrm{Pb}$, in the majority of samples tested, its quantities are greater than the concentrations found in 
$\mathrm{Pb}$

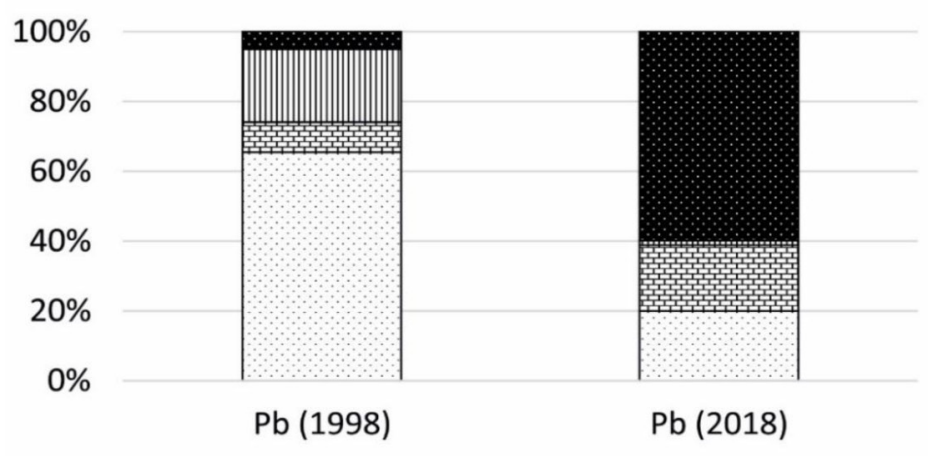

$\mathrm{Zn}$

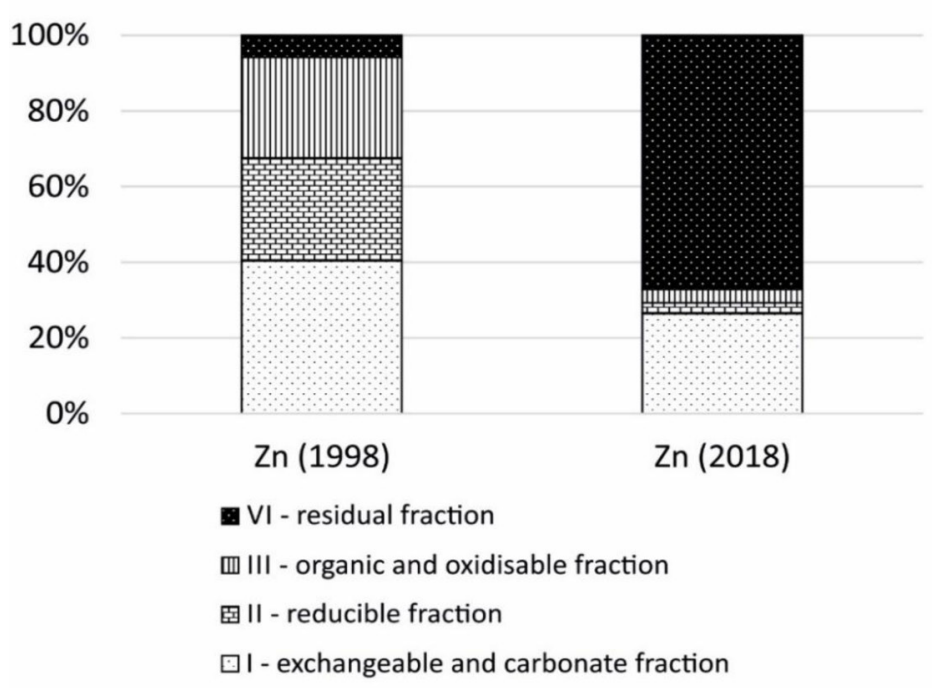

Figure 4. Share (\%) of the $\mathrm{Pb}$ and $\mathrm{Zn}$ - binding fractions in the top layer soil samples (average for site no. 2)

the samples collected 20 years earlier, with the samples from site no. 4 being the only exception. In the case of $\mathrm{Zn}$, the concentration was considerably lower in all locations (Tab. 2). Comparing the concentrations determined with the limits set in the Regulation of the Minister of the Environment (Regulation 2014) on the conditions to be met when discharging sewage to water or soil, and on substances particularly harmful to the aquatic environment, it wasfound that the hazard level related to the presence of $\mathrm{Pb}$ and $\mathrm{Zn}$ in the soils in sampling site no. 1 is high. In this site, the permissible concentrations set forth in the abovementioned Regulation were exceeded by $218 \%$ $(\mathrm{Pb})$ and $49 \%(\mathrm{Zn})$. All the samples collected in 2018 demonstrated that $\mathrm{Pb}$ posed hazard to the water environment, while 20 years earlier such hazard was caused by the presence of $\mathrm{Zn}$ in the soils in the vicinity of the zinc-works.

The purpose of this extraction was to evaluate the hazard to plants caused by the presence of $\mathrm{Pb}$ and $\mathrm{Zn}$. The quantities of $\mathrm{Pb}$ extracted using $0.11 \mathrm{M}$
EDTA solution from soil samples collected in 2018 ranged from 430 to $7,235 \mathrm{mg} / \mathrm{kg}$, which amounted to $11-39 \%$ of the total content of this metal in soils (Table 3). In 2018, the absolute values were on average twice higher $\left(\mathrm{Me}_{1998}=2,058 \mathrm{mg} / \mathrm{kg} v \mathrm{~s}\right.$. $\mathrm{Me}_{2018}=4,482 \mathrm{mg} / \mathrm{kg}$ ). However, the percentage share of this fraction in the total content was halved i.e. in 2018 the average share was 30\%, while two decades earlier it was $66 \%$.

In the case of $\mathrm{Zn}$, the quantities extracted in this analytical procedure from samples collected in 2018 ranged from 476 to $11,469 \mathrm{mg} / \mathrm{kg}(\mathrm{Me}=4,010 \mathrm{mg} / \mathrm{kg})$, which amounted to $14-52 \%$ of the total content $(34 \%$ for all samples). In 1998, the same quantities amounted to $414-1,451 \mathrm{mg} / \mathrm{kg}(\mathrm{Me}=812 \mathrm{mg} / \mathrm{kg})$, which equaled $3-54 \%$ ( $44 \%$ for all samples). Thus, in the case of $\mathrm{Zn}$ the situation is similar to $\mathrm{Pb}$ : between 1998 and 2018, the absolute quantity of phytoavailable $\mathrm{Zn}$ increased 5 times, while its percentage share in the total content decreased by 10 percentage points. 
Table 2. The $\mathrm{pH}$ and concentrations of $\mathrm{Pb}$ and $\mathrm{Zn}$ extracted by water solution from soil samples

\begin{tabular}{|c|c|c|c|c|}
\hline \multirow{3}{*}{ Sample sites } & \multicolumn{2}{|c|}{$\mathrm{Pb}$} & \multicolumn{2}{|c|}{$\mathrm{Zn}$} \\
\hline & 1998 & 2018 & 1998 & 2018 \\
\hline & \multicolumn{4}{|c|}{$\mathrm{mg} \cdot \mathrm{dm}^{-3}$} \\
\hline 1 & 0.19 & 1.59 & 3.52 & 2.99 \\
\hline 2 & 0.05 & 0.55 & 2.78 & 0.61 \\
\hline 3 & 0.17 & 0.21 & 0.48 & 0.22 \\
\hline \multirow[t]{2}{*}{4} & 0.41 & 0.10 & 1.44 & 0.84 \\
\hline & \multicolumn{3}{|c|}{ For all samples $(n=40)$} & \\
\hline $\mathrm{Me}$ & 0.18 & 0.55 & 2.11 & 0.61 \\
\hline Upper limit ${ }^{1}$ & 0.50 & 0.50 & 2.00 & 2.00 \\
\hline
\end{tabular}

${ }^{1}$ According to the Regulation of the Minister of Environment (2014), in bold - values above the limit.

In the experiment involving soil acidification using 7 doses of $\mathrm{HNO}_{3}$ (between 0 and $120 \mathrm{mmol}$ ), the buffering capacity of soil was verified together with the quantities of elements released into the solution as a result of decreasing $\mathrm{pH}$. The buffering capacity of the soil represents its ability to oppose the $\mathrm{pH}$ changes which occur mostly as a result of introducing pollutants (e.g. SOx, NOx) to the environment. This is an important parameter reflecting the geochemical characteristics of the material studied, especially in the areas where acid rains occur.

The tests conducted demonstrated that despite the good buffering capacity of soil, each addition of acid increased the quantity of the released $\mathrm{Pb}$ and $\mathrm{Zn}$ ions (Fig. 5). Maximum acidity i.e. fol-

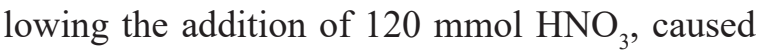
the decrease of $\mathrm{pH}$ by $3-4$ units and at the same time the release of 1 to $90 \%$ of the total $\mathrm{Pb}$ content (mean value for all samples amounting to $58 \%$ ) and 36 to $93 \%$ of the total $\mathrm{Zn}$ content (mean value for all samples amounting to $60 \%$ ).

It was demonstrated that $\mathrm{Zn}$ is more readily released from the soil than $\mathrm{Pb}$, which stems from its geochemical characteristics. $\mathrm{Zn}$ is one of the most mobile elements in the soil and all its compounds are readily soluble, especially in acidic environments. Kabata-Pendias and Pendias (1999) explain this phenomenon by the creation of highly-mobile mineral or organicmineral connections by the released $\mathrm{Zn}$ ions. Lead, on the other hand, is slowly released in the weathering processes. It has relatively low mobility and creates complex ions which regulate the sorption and desorption processes to a considerable extent.

\section{Environmental risk}

\section{Contamination Factor}

The Contamination Factor calculated based on the $\mathrm{Pb}$ and $\mathrm{Zn}$ content in the soil samples collected in 2018 clearly indicates a very high degree of contamination, regardless of the value used as geochemical background (Tab. 4). When using either natural content or upper limits stipulated in Regulation (Regulation 2016) for the category II and IV soils, the calculated value is always $\mathrm{CF}>6$. In the case of the samples collected in 1998, when using the upper limits for the category II soils $(100 \mathrm{mg} / \mathrm{kg}$ for $\mathrm{Pb}$ and $300 \mathrm{mg} / \mathrm{kg}$ for $\mathrm{Zn})$ and the category IV soils $(600 \mathrm{mg} / \mathrm{kg}$ for $\mathrm{Pb}$ and

Table 3. Concentrations of $\mathrm{Pb}$ and $\mathrm{Zn}$ extracted by $0.11 \mathrm{M}$ EDTA solution from soil samples

\begin{tabular}{|c|c|c|c|c|}
\hline \multirow{3}{*}{ Sampling sites } & \multicolumn{2}{|c|}{$\mathrm{Pb}$} & \multicolumn{2}{|c|}{$\mathrm{Zn}$} \\
\hline & 1998 & 2018 & 1998 & 2018 \\
\hline & \multicolumn{4}{|c|}{$\mathrm{mg} \cdot \mathrm{kg}^{-1}(\%)^{1}$} \\
\hline 1 & $1267(57)$ & $7235(28)$ & $1076(37)$ & $6343(30)$ \\
\hline 2 & $5728(48)$ & $3052(39)$ & $414(3)$ & $1677(37)$ \\
\hline 3 & $504(84)$ & $430(11)$ & $548(54)$ & $476(14)$ \\
\hline 4 & $2849(76)$ & $5913(32)$ & $1451(51)$ & $11,469(52)$ \\
\hline \multicolumn{5}{|c|}{ for all samples $(n=40)$} \\
\hline $\mathrm{Me}$ & $2058(66)$ & $4482(30)$ & $812(44)$ & $4010(34)$ \\
\hline
\end{tabular}

\footnotetext{
$1 \%$ of total concentration.
} 

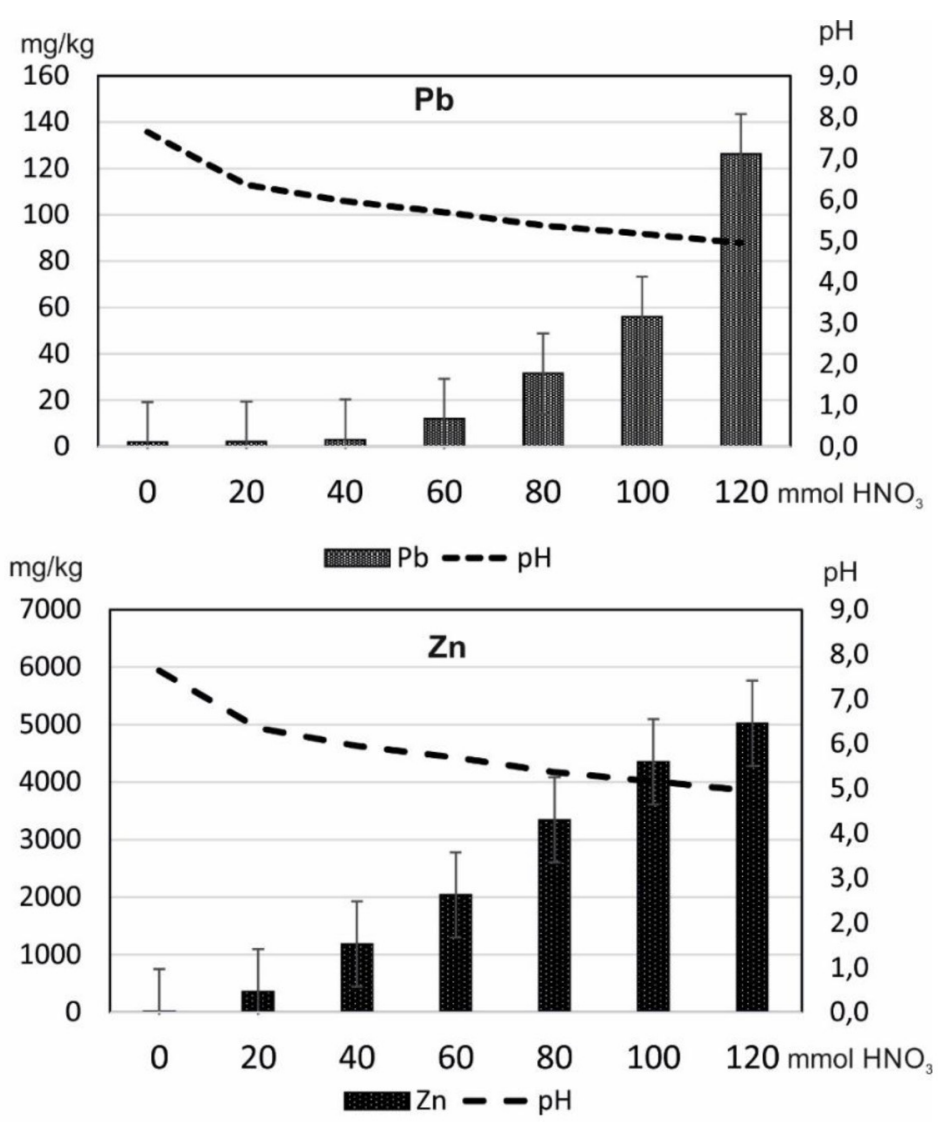

Figure 5. Leaching of $\mathrm{Pb}$ and $\mathrm{Zn}$ from the soil samples (1998) as a result of acidification

$2000 \mathrm{mg} / \mathrm{kg}$ for Zn), was observed that the situation improved slightly. In the case of $\mathrm{Zn}$, a considerable and moderate degree of contamination was found, while in the case of $\mathrm{Pb}-$ a very high degree of contamination was observed.

The increase of the calculated CF values between the years 1998 and 2018 is worrying. In 1998 , the CF values amounted to 51 in the case of $\mathrm{Pb}$ and 52 in the case of $\mathrm{Zn}$, while 20 years later they reached 157 and 127, respectively. This confirms that the environment pollution level is high.

\section{Geoaccumulation Index and Pollution Load Index}

The situation was similar with $\mathrm{I}_{\text {geo, }}$, which takes into consideration a small anthropogenic impact. For the samples collected in 2018, $\mathrm{I}_{\mathrm{geo}}$ calculated for $\mathrm{Pb}$ and $\mathrm{Zn}$ amounted to 105 and 84 respectively, which indicates the highest VI pollution class i.e. extremely polluted (Tab. 5). When using upper limits set forth in the Regulation of the Minister of the Environment as $\mathrm{Pb}$ geochemical background (i.e. 100 and $600 \mathrm{mg} / \mathrm{kg}$ ), the situation

Table 4. Contamination Factor (CF) calculated for the $\mathrm{Pb}$ and $\mathrm{Zn}$ content in 1998 and 2018 in the soils collected in Zn-works surrounding

\begin{tabular}{|c|c|c|c|c|}
\hline \multirow{2}{*}{$\mathrm{CF}$} & \multicolumn{2}{|c|}{1998} & \multicolumn{2}{|c|}{2018} \\
\cline { 2 - 5 } & $\mathrm{Pb}$ & $\mathrm{Zn}$ & $\mathrm{Pb}$ & $\mathrm{Zn}$ \\
\hline $\mathrm{CF}^{1}$ & $\mathrm{VH}$ & $\mathrm{VH}$ & $\mathrm{VH}$ & $\mathrm{VH}$ \\
\hline $\mathrm{CF}^{2}$ & $\mathrm{VH}$ & $\mathrm{C}$ & $\mathrm{VH}$ & $\mathrm{VH}$ \\
\hline $\mathrm{CF}^{3}$ & $\mathrm{VH}$ & $\mathrm{M}$ & $\mathrm{VH}$ & $\mathrm{VH}$ \\
\hline
\end{tabular}

$\mathrm{CF}$ calculated based on the GB values according to:

${ }^{1}$ Kabata-Pendias and Pendias (2000);

${ }^{2}$ Regulation of the Ministry (2016) for II category of soil;

${ }^{3}$ Regulation of the Ministry (2016) for IV category of soil; L - low degree of contamination (CF $\left.<1\right)$; $\mathrm{M}-$ moderate degree of contamination $(1 \leq \mathrm{CF}<3)$; $\mathrm{C}$ - considerable degree of contamination $(3 \leq \mathrm{CF}<6)$; VH - very high degree of contamination $(\mathrm{CF} \geq 6)$. 
Table 5. Geo-accumulation index $\left(\mathrm{I}_{\text {geo }}\right)$ calculated for the $\mathrm{Pb}$ and $\mathrm{Zn}$ content in 1998 and 2018 year in soils collected next to the Zn-works

\begin{tabular}{|c|c|c|c|c|}
\hline \multirow{2}{*}{$\mathrm{I}_{\text {geo }}$} & \multicolumn{2}{|c|}{1998} & \multicolumn{2}{c|}{2018} \\
\cline { 2 - 5 } & $\mathrm{Pb}$ & $\mathrm{Zn}$ & $\mathrm{Pb}$ & $\mathrm{Zn}$ \\
\hline $\mathrm{I}_{\text {geo }}{ }^{1}$ & $\mathrm{VI}$ & $\mathrm{VI}$ & $\mathrm{VI}$ & $\mathrm{VI}$ \\
\hline $\mathrm{I}_{\text {geo }}^{2}$ & $\mathrm{VI}$ & $\mathrm{IV}$ & $\mathrm{VI}$ & $\mathrm{III}$ \\
\hline $\mathrm{I}_{\text {geo }}^{3}$ & $\mathrm{VI}$ & $\mathrm{II}$ & $\mathrm{VI}$ & \\
\hline
\end{tabular}

$\mathrm{I}_{\text {geo }}$ calculated based on the GB values according to: ${ }^{1}$ Kabata-Pendias and Szteke (2012); ${ }^{2}$ Regulation of the Ministry (2016) for II category of soil; ${ }^{3}$ Regulation of the Ministry (2016) for IV category of soil; 0 - unpolluted ( $\left.\mathrm{I}_{\text {geo }} \leq 0\right)$; I - from unpolluted to moderately polluted $\left(0<\mathrm{I}_{\mathrm{geo}} \leq 1\right)$; II - moderately polluted $\left(1<\mathrm{I}_{\mathrm{geo}} \leq 2\right)$; III - from moderately polluted to strongly polluted $\left(2<\mathrm{I}_{\text {geo }} \leq 3\right) ; \mathrm{IV}-$ strongly polluted $\left(3<\mathrm{I}_{\text {geo }} \leq 4\right) ; \mathrm{V}-$ from strongly polluted to extremely polluted $\left(4<\mathrm{I}_{\text {geo }} \leq 5\right)$; VI - extremely polluted $\left(\mathrm{I}_{\text {geo }}>5\right)$.

does not improve. The pollution class remains VI in the case of the samples collected in 1998 and in 2018. In the case of Zn, when using upper limits set forth in the Regulation of the Minister of the Environment (i.e. 300 and $2000 \mathrm{mg} / \mathrm{kg}$ ), the pollution class increases. In 1998, this was class IV (strongly polluted) and class II (moderately polluted), while in the year 2018 it was class VI (extremely polluted) and class III (moderatelystrongly polluted).

Taking into consideration the concentration of both elements in relation to all 3 reference values i.e. natural content and limits set for category II and IV soils as specified in the Regulation by the Minister of the Environment (Regulation 2016), the aggregate Pollution Load Index $(P L I)$ amounted to 11,3 and 2, respectively, in the case of the samples collected in 1998. PLI calculated for the samples collected in 2018 was considerably higher and amounted to 21, 5 and 4, respectively. Given that all values were $P L I>1$, it may be concluded that the soils in the vicinity of the zinc-works are strongly polluted with $\mathrm{Pb}$ and $\mathrm{Zn}$.

\section{Risk Assessment Code}

The final parameter used in the environmental risk assessment is the Risk Assessment Code. Similarly to the indices and factors listed earlier, RAC was calculated for all the samples collected in 1998 and in 2018 (Tab. 6). Due to the considerable variation of the $\mathrm{Pb}$ and $\mathrm{Zn}$ content in soils (see: $V$ - coefficient of variation, Tab. 1), the RAC values were analysed for all sampling sites. The following fractions were considered most hazardous for the environment: (1) the amount of cations extracted using the 0.11 M EDTA solution, as it is a fraction that is readily absorbed by plants and may easily enter the trophic chain; and (2) the amount of cations extracted in Step I of BCR (ion-exchange

Table 6. Risk Assessment Code (RAC) calculated for the $\mathrm{Pb}$ and $\mathrm{Zn}$ content in 1998 and 2018 year in soils collected next to the Zn-works

\begin{tabular}{|c|c|c|c|c|}
\hline \multirow{2}{*}{ Sampling sites } & \multicolumn{2}{|c|}{1998} & \multicolumn{2}{|c|}{2018} \\
\hline & $\mathrm{Pb}$ & $\mathrm{Zn}$ & $\mathrm{Pb}$ & $\mathrm{Zn}$ \\
\hline \multicolumn{5}{|c|}{$\mathrm{RAC}^{1}$} \\
\hline 1 & $\mathrm{VH}$ & $\mathrm{H}$ & $M$ & $\mathrm{H}$ \\
\hline 2 & $\mathrm{H}$ & $\mathrm{L}$ & $\mathrm{H}$ & $\mathrm{H}$ \\
\hline 3 & $\mathrm{VH}$ & $\mathrm{VH}$ & $M$ & $M$ \\
\hline 4 & $\mathrm{VH}$ & $\mathrm{VH}$ & $\mathrm{H}$ & $\mathrm{VH}$ \\
\hline For all samples & $\mathrm{VH}$ & $\mathrm{H}$ & $\mathrm{H}$ & $\mathrm{H}$ \\
\hline \multicolumn{5}{|c|}{$\mathrm{RAC}^{2}$} \\
\hline 1 & $\mathrm{H}$ & $\mathrm{H}$ & $M$ & $\mathrm{H}$ \\
\hline 2 & $\mathrm{VH}$ & $\mathrm{H}$ & $\mathrm{H}$ & $\mathrm{H}$ \\
\hline 3 & $\mathrm{VH}$ & $\mathrm{VH}$ & $\mathrm{L}$ & $M$ \\
\hline 4 & $\mathrm{H}$ & $\mathrm{H}$ & $\mathrm{H}$ & $\mathrm{VH}$ \\
\hline For all samples & VH & $\mathrm{H}$ & $\mathrm{H}$ & $\mathrm{H}$ \\
\hline
\end{tabular}

$\mathrm{RAC}^{1}$ - based on (\%) extracted by the EDTA solution; RAC ${ }^{2}$ - based on (\%) extracted by the I step of BCR; N - no risk $(\mathrm{RAC}<1) ; \mathrm{L}-$ low risk $(1 \leq \mathrm{RAC}<10) ; \mathrm{M}-$ medium risk $(10 \leq \mathrm{RAC}<30) ; \mathrm{H}-$ high risk $(30 \leq \mathrm{RAC}<50)$; $\mathrm{VH}-$ very high risk $(50 \leq \mathrm{RAC})$. 
cations and cations bound with carbonates), as it is considered a readily mobile fraction.

In the year 1998, RAC calculated using (1) ranged from high to very high risk in the case of $\mathrm{Pb}$ and from low to very high risk in the case of $\mathrm{Zn}$. When using (2), the situation was identical in the case of $\mathrm{Pb}$, while for $\mathrm{Zn}$ it deteriorated slightly as the RAC ranged from high to very high risk.

The mean result for the year 1998 for all the samples collected ( $n=40)$ using (1) and (2) yielded high risk for $\mathrm{Pb}$ and high risk for $\mathrm{Zn}$. In the case of the samples collected in 2018, RAC calculated for $\mathrm{Pb}$ using (1) was medium to high risk, while with (2) - it was low to high risk. For Zn, RAC ranged from medium to high risk in the case of both (1) and (2). The mean RAC for the year 2018 for all samples collected $(n=40)$ indicated high environmental risk in the case of both $\mathrm{Pb}$ and $\mathrm{Zn}$. This means that the situation improved slightly over the period of 20 years.

The above-mentioned analysis also demonstrated the importance of collecting the right number of samples, especially in the strongly polluted areas with varying levels of pollution. Additionally, it seems that it is better to perform the environmental risk analyses not only for the total content but also for the readily mobile and phytoavailable forms of elements.

\section{DISCUSSION}

Pollution with $\mathrm{Zn}$ and $\mathrm{Pb}$ as well as compounds of these metals and their accompanying elements in the vicinity of metal-works processing them is common and well documented in numerous scientific papers. Akopyan et al. (2018) found that in the soils around the mining towns in Armenia, the content of $\mathrm{Pb}$ and As reaches $30,083 \mathrm{mg} / \mathrm{kg}$ and $276 \mathrm{mg} / \mathrm{kg}$, respectively, so the environmental risk related to these elements is considerable. The studies onthe heavy metal contents in soils of another region known for the presence and processing of $\mathrm{Zn}-\mathrm{Pb}$ ores in Poland (Olkusz-Bukowno) were conducted in the 1960s (Kicińska 2019b, Stefanowicz et al. 2014). The highest concentrations of $\mathrm{Zn}, \mathrm{Pb}$ and $\mathrm{Cd}$ in soils were found in the locations where historically the ores of these elements were excavated and processed. In the regions where the $\mathrm{Zn}-\mathrm{Pb}$ ores were processed, the content of metals amounted to: $\mathrm{Zn}-25,000 \mathrm{mg} / \mathrm{kg}, \mathrm{Pb}-5,000 \mathrm{mg} / \mathrm{kg}$, Cd-129 mg/kg, Tl-39 mg/kg. Additionally, increased concentrations of $\mathrm{Fe}$ and $\mathrm{Mn}$ were found
(Cabała 2009). The highest concentrations of metals were encountered in the soil samples collected from the depth up to $25 \mathrm{~cm}$ below ground level. In the deeper layers, the contents of metals decreased considerably (Kicińska-Świderska 1999). Lead $(\mathrm{Pb})$ was accumulated in the top layers of soil, while $\mathrm{Cd}$ and $\mathrm{Zn}$ were more evenly distributed in the soil profile due to their greater mobility (Kabata-Pendias 1989). In their papers, Ghayoraneh, Qishlaqi (2017) and Shen et al. (2017) indicated a $50-75 \%$ decrease of the $\mathrm{Zn}$ and $\mathrm{Pb}$ contents in soil profiles as the depth increased.

The problem of soil pollution in the vicinity of metal-works was also studied by Liu et al. (2018) and Cortada et al. (2018). In Shaoguan City (China), Liu et al. (2018) found high concentrations of $\mathrm{Cd}, \mathrm{Zn}, \mathrm{Pb}$ and $\mathrm{Cu}$ in the soils near the $\mathrm{Zn}-\mathrm{Pb}$ processing plants. The $\mathrm{I}_{\text {geo }}$ indices calculated for $\mathrm{Cd}, \mathrm{Zn}, \mathrm{Pb}$ and $\mathrm{Cu}$ were greater than 5 , denoting extreme contamination (class VI). Cortada et al. (2018) point to metallurgical plants (metal-works) and two different mechanisms of pollution dispersal as the major causes of extreme pollution levels. The first mechanism is related to the emission of gas and dust produced by metallurgical processes and their transport by the prevailing winds. The second is associated with the leachate produced in smelter residues.

The long-term mining and processing of the $\mathrm{Zn}-\mathrm{Pb}$ ores in mining and industrial areas cause significant changes in the dominating forms of elements as discussed by e.g. Liu et al. (2018), Ghayoraneh and Qishlaqi (2017). This may pose a serious hazard due to the potential immobilisation and biological absorption of elements (De Miguel et al. 2018, Maskall et al. 1996, Kicińska et al. 2019). The inhabitants of the areas in the closest vicinity of metal-works are at risk of much greater impact of toxic elements, as discussed by Akopyan et al. (2018), Barrio-Parra et al. (2017) and Ghayoraneh and Qishlaqi (2017).

\section{CONCLUSIONS}

On the basis of the laboratory experiments and field studies conducted over a period of twenty years, the following conclusions were formulated:

1) The pseudo-total contents of $\mathrm{Pb}$ and $\mathrm{Zn}$ in the surface soil samples collected in 2018 amounted to: 3,975-26,200 and 3,358-21,867 (mg/ $\mathrm{kg}$ ), respectively, and are on average four times 
higher than the values determined 20 years earlier in the same sites i.e. 601-11,939 and $1,009-13,924(\mathrm{mg} / \mathrm{kg})$, respectively.

2) In all the soil samples collected in 2018, the upper limits of the $\mathrm{Pb}$ and $\mathrm{Zn}$ content set forth in legal regulations as well as their "natural content" were considerably exceeded.

3) The zinc-works itself is no longer the main source of pollution as was the case in 1998. Instead, in 2018 the main sources of emissions were the erosion and deflation processes in the old, unprotected mining and industrial waste dumps located near the metal-works.

4) The most polluted soil layers are the profile surface layers. The contents of $\mathrm{Pb}$ and $\mathrm{Zn}$ determined in them were 4 times greater than those in the layers located deeper in the profiles. Even though the concentrations of elements decrease considerably as the depth increases, the natural levels were exceeded, which confirms the longterm penetration of elements into the soil profile.

5) Over the last 20 years, a positive environmental change has occurred. It is related to an increase in the share of sparingly soluble fractions, as well as the fractions integrated into the crystal structures of minerals (residual fraction). The quantity of these fractions increased by $55 \%$ for $\mathrm{Pb}$ and by as much as $61 \%$ for $\mathrm{Zn}$. Thus, the number of readily exchangeable fractions (i.e. ion exchange and bound with carbonates) decreased.

6) Despite the good buffer properties of soils in the study area, a decrease in $\mathrm{pH}$ may cause the release of considerable quantities of $\mathrm{Pb}$ (up to $58 \%$ of the total content) and $\mathrm{Zn}$ (up to $60 \%$ of the total content).

7) Based on the readily available/mobile fraction and geochemical background values used in the the environmental risk calculations, the following conclusions pertaining to period of the past two decades were formulated:

- the comparison between the determined and the natural content of lead and zinc has indicated that the contamination with $\mathrm{Pb}$ and $\mathrm{Zn}$ as well as the ecological risk related to these elements have been very high,

- with limits for category II and IV soils used as reference values, the condition of the soil environment has deteriorated,

- conversely, there has been a small improvement in the environmental conditions pertaining to the forms of elements and the quantities of readily mobile $\mathrm{Pb}$ forms, which is a positive change signifying that the ecosystems are recovering.

\section{Acknowledgements}

This research was financial support by AGH grant no. 16.16.140.315.

\section{REFERENCES}

1. Akopyan K., Petrosyan V., Grigoryan R., Melkomian D.M. 2018. Assessment of residential soil contamination with arsenic and lead in mining and smelting towns of northern Armenia, Journal of Geochemical Exploration, 184: 97-109, doi:10/1016/j. gexplo.2017.10.010.26.

2. Bączek-Kwinta R., Antonkiewicz J., Łopata-Stasiak A., Kępka W. 2019. Smoke compounds aggravate stress inflicted on Brassica seedlings by unfavourable soil conditions. Photosynthetica, 57, 1, 1-8. doi: $10.32615 /$ ps.2019.026

3. Barrio-Parra F., Elío J., De Miguel E., GarcíaGonzález J.E., Izquierdo M., Álvarez R. 2017. Environmental risk assessment of cobalt and manganese from industrial sources in an estuarine system. Environ Geochem Health, 1-12. doi:10.1007/ s10653-017-0020-9

4. Cabała J. 2009. Heavy metals in the soil environment of the Olkusz Zn-Pb ore mining area. Ed. UŚ, Katowice, 128, [in Polish].

5. Central Statistical Office, 2019. Pollution and air protection. Poland.

6. Cortada U., Hidalgo C., Martínez J., Rey J. 2018. Impact in soils caused by metal(loid)s in lead metallurgy. The case of La Cruz Smelter (Southern Spain). Journal of Geochemical Exploration, 190: 302-313, doi:10.1016/j.gexplo.2018.04.001.

7. Data on Poland, http://www.oecd.org/poland/

8. De Miguel E., Ordóñez A., Barrio-Parra F., IzquierdoDíaz M., Álvarez R., Mingot J., Charlesworth S.M. 2018.Bioaccessibility of Trace Elements in Urban Environments, in: Charlesworth, Susanne M., Booth, C.A. (Eds.), Urban Pollution: Science and Management. Wiley-Blackwell, Hoboken, NJ, 107-113.

9. Dziubanek G., Baranowska R., Ćwieląg-Drabek M., Spychała A., Piekut A., Rusin M. 2017. Cadmium in edible plants from Silesia, Poland, and its implications for health risk in populations. Ecotoxicology and Environmental Safety,142, 8-13.

10. Ghayoraneh M., Qishlaqi A. 2017. Concentration, distribution and speciation of toxic metals in soils along a transect around a $\mathrm{Zn} / \mathrm{Pb}$ smelter in the northwest of Iran. Journal of Geochemical Exploration, 180: 1-14, doi: 10.1016/j.gexplo.2017.05.007.

11. Hadzi G.Y., Ayoko G.A., Essumang D.K, et al. 2019. Contamination impact and human health risk assessment of heavy metals in surface soils from selected major mining areas in Ghana, Environ Geochem Health, doi: 10.1007/s10653-019-00332-4. 
12. Håkanson L. 1980. An ecological risk index for aquatic pollution control. A sedimentological approach. Water Research, 14, 8: 975-1001.

13. Jena S., Perwez A., Singh G. 2019. Trace element characterization of fine particulate matter and assessment of associated health risk in mining area, transportation routes and institutional area of Dhanbad, India. Environ Geochem Health, doi: 10.1007/ s10653-019-00329-z.

14. Kabata-Pendias A. 1989. Pollutants with trace elements of agricultural land. [In]: Selected issues related to chemical soil pollution. Scientific Committee at the Presidium of the Polish Academy of Sciences, Man and Environment, Wrocław, [in Polish].

15. Kabata-Pendias A., Pendias H. 2000. Trace elements in soils and plants. CRC Press, BocaRaton

16. Kapusta P., Stanek M., Szarek-Łukaszewska G., Godzik, B. 2019.Long-term moss monitoring of atmospheric deposition near a large steelworks reveals the growing importance of local non-industrial sources of pollution.Chemosphere, doi: 10.1016/j. chemosphere.2019.05.058.16.

17. Kicińska A., Smreczak B., Jadczyszyn J. 2019. Soil Bioavailability of Cadmium, Lead, and Zinc in the Areas of $\mathrm{Zn}-\mathrm{Pb}$ Ore Mining and Processing (Bukowno, Olkusz). Journal of Ecological Engineering, 20,1: 84-92, doi: 10.12911/22998993/93794.

18. Kicińska A. 2019a. Chemical and mineral composition of fly ashes from home furnaces, and health and environmental risk related to their presence in the environment. Chemosphere, 215: 574-585, doi: 10.1016/j.chemosphere.2018.10.061.

19. Kicińska A. 2019b. Environmental risk related to presence and mobility of $\mathrm{As}, \mathrm{Cd}$ and $\mathrm{Tl}$ in soils in the vicinity of a metallurgical plant - Longterm observations. Chemosphere, doi: 10.1016/j. chemosphere.2019.07.039

20. Kicińska A. 2018. Health risk assessment related to an effect of sample size fractions: methodological remarks. Stoch Environ Res Risk Assess, 32: 1867-1887, doi.org/10.1007/s00477-017-1496-7.

21. Kicińska A. 2016. Risk assessment of children's exposure to potentially harmful elements (PHE) in selected urban parks of the Silesian agglomeration. E3S Web of Conferences, 10 Article Nr: UNSP 00035, doi: 10.1051/e3sconf/20161000035.

22. Kicińska A., Bożęcki P. 2018. Metals and mineral phases of dusts collected in different urban parks of Krakow and their impact on the health of city residents. Environ Geochem Health, 40: 473-488, doi:10.1007/s10653-017-9934-5.

23. Kicińska A., Jelonek-Waliszewska A. 2017. As and $\mathrm{Pb}$ and their potential source in the hair of residents of Cracow. Journal of Elementology, 22, 2: $517-$ 528, doi: 10.5601/jelem.2016.21.3.1223.
24. Kicińska-Świderska A. 1999. Heavy metals in soils and plants in selected areas of the steel industry's impact. PhD thesis, AGH, Kraków [In Polish].

25. Kicki J. Technology of exploitation of $\mathrm{Zn}$ and $\mathrm{Pb}$ ore deposits. IGSMiE PAN, Kraków. 1997,

26. Kosa B., Kicińska A. Coal from the waste disposal site of the Siersza mine (Trzebinia, Poland) and its properties as a possible alternative fuel. E3S Web of Conferences, 2016: 10 Article Nr: UNSP 00039, doi: 10.1051/e3sconf/20161000039.

27. Liu T., Li F., Jin Z., Yang Y. 2018. Acidic leaching of potentially toxic metals $\mathrm{Cd}, \mathrm{Co}, \mathrm{Cr}, \mathrm{Cu}, \mathrm{Ni}, \mathrm{Pb}$, and $\mathrm{Zn}$ from two $\mathrm{Zn}$ smelting slag materials incubated in an acidic soil, Environmental Pollution, 238: 359-368, doi: 10.1016/j.envpol.2018.03.022.

28. Manouchehri N., Besancon S., Bermond A. 2006. Major and trace metal extraction from soil by EDTA: Equilibrium and kinetic studies. Analytica Chimica Acta,559,1: 105-112, doi: 10.1016/j. aca.2005.11.050.

29. Maskall J., Whitehead K.C., Thornton, I. 1996. Long-term migration of metals at historical smelting sites. Applied Geochemistry, 11: 43-51.

30. Müller G. 1981. The heavy metal pollution of the sediments of Neckars and its tributary. A Stock taking Chemische Zeit, 150: 157-164.

31. Nowińska K. 2003. Distribution of some trace elements on the way from the concentrate of $\mathrm{Zn}-\mathrm{Pb}$ ore to waste on the example of the zinc smelter Miasteczko Śląskie. PhD thesis, Silesian University of Technology, Gliwice [in Polish].

32. Qui H. 2010. Studies on the potential ecological risk and homology correlation of heavy metal in the surface soil. Journal of Agricultural Science,2(2), 194-201.

33. Regulation of the Minister of Environment of November 18, 2014 on the conditions to be met when discharging sewage to water or soil, and on substances particularly harmful to the aquatic environment (Dz. U. 2014, item 1800).

34. Regulation of the Minister of the Environment 2016 on the assessment of ground pollution (Dz. U. 2016, item 1395).

35. Shen F., Liao R., Ali A., Mahar A., Guo D., Li R., Sun X., Awasthi M.K., Wang Q., Zhang Z. 2017. Spatial distribution and risk assessment of heavy metals in soil near a $\mathrm{Pb} / \mathrm{Zn}$ smelter in Feng County, China. Ecotoxicology and Environmental Safety, 139: 254-262, doi: 10.1016/j.ecoenv.2017.01.044.

36. Sparks D.L. 1996. Methods of soil analysis: Part 3. Chemical methods. Soil Science Society of America, 445 Madison, WI.

37. Stefanowicz, A.M., Woch, M.W., Kapusta, P. 2014. Inconspicuous waste heaps left by historical $\mathrm{Zn}-\mathrm{Pb}$ mining are hot spots of soil contmaination. Geoderma, 235-236: 1-8. 